\title{
Optimalisasi Pembinaan Narapidana dalam Upaya Mengurangi Overcapacity Lembaga Pemasyarakatan
}

\author{
Risang Achmad Putra Perkasa \\ Politeknik Ilmu Pemasyarakatan \\ Correspondence email: risangachmad98@gmail.com
}

\begin{abstract}
Abstrak. Overcapacity terjadi karena adanya laju pertumbuhan penghuni di lembaga pemasyarakatan yang tidak sebanding dengan jumlah hunian di dalam lembaga pemasyarakatan, selain itu terdapat faktor lain terjadinya over capaity, seperti paradigma atau faktor hukuman yang di terima narapidana itu sendiri cenderung berorientasi pada pidana institusional atau penjara. Hal ini cenderung berimplikasi negatif terhadap benyak hal antara lain rendahnya tingkat pengawasan dan pengamanan serta terjadinya prisonisasi. Solusi overcapaity narapidana yang berada di dalam lembaga pemasyarakatan antara lain adanya tindakan yang bersifat non instuisional berupa pidana bersyarat, probation, pidana yang di tangguhkan, kompensasi, restitusi serta penggunaan restorative justice.
\end{abstract}

Kata Kunci: Narapidana, Overcapacity, Restorative justice

Abstract. Overcapacity occurs because of the growth rate of inmates in prison that is not proportional to the number of dwellings in correctional institutions, besides that there are other factors of overcapaity, such as paradigms or factors of punishment received by prisoners themselves tend to be oriented towards institutional criminal or prison. This tends to have negative implications on a number of things including the low level of supervision and security and the occurrence of imprisonment. The overcapaity solution for prisoners inside the correctional facility includes non-institutional actions in the form of conditional penalties, probation, suspended crimes, compensation, restitution and the use of restorative justice.

Keywords: Inmate, Overcapacity, Restorative justice.

\section{PENDAHULUAN}

Sebagaimana yang terdapat pada UU No. 12 Tahun 1995, dijelaskan bahwa Lembaga pemasyarakatan merupakan salah satu bagian dari tatanan peradilan pidana yang berfungsi sebagai tempat penyelenggara hukuman sekaligus sebagai tempat pembinaan bagi narapidana.

Pemberian pembinaan tersebut tidak hanya untuk memyadarkan diri seorang narapidana atas kesalahan yang telah dilakukan tetapi juga dapat dikatakan sebagai pemberian pendidikan bagi narapidana yang berada di dalam lembaga permasyarakatan, sebagai upaya menciptakan karakter positif pada diri narapidana. Sehingga pada saat ia bebas dari hukuman pidana, ia bisa menjadi pribadi yang berkarakter dan mampu membaur dengan lingkungan masyarakat. Hal tersebut sesuai dengan SK Menteri Kehakiman Republik Indonesia no.02-PK.04.10 tahun 1990 mengenai Pola Pembinaan narapidana menyatakan bahwa lapas sebagai tempat penyelenggara pidana penjara (pengasingan) juga memiliki sasaran yang sangat strategis antara lain lapas mengemban fungsi ganda yaitu sebagai lembaga edukasi dan lembaga pembentukan karaktakter narapidana.

Sebagaimana sebuah lembaga edukasi , lembaga permasyarakatan harus mendidik narapidana agar nantinya dapat menjadi pribadi yang berkualitas, yaitu beriman dan bertaqwa kepada Tuhan Yang Maga Esa, berakhlak mulia, memiliki kemampuan inteligensia dan memiliki kesadaran dengan hukum. Sebagai lembaga pembentuk karakter, lapas bertugas menjadikan narapidana sebagai pribadi yang membangun produktif, saat ia berada didalam penjara ataupun saat ia kembali ke masyarakat serta mendompleng pembangunan kesusksesan di tengah tengah masyarakat ${ }^{1}$.

Akan tetapi faktanya terdapat banyak kendala saat melakukan pembinaan terhadap narapidana, sehingga pada pelaksanaannya pembinaan yang diberikan belum dapat dilakukan secara optimal. Di Indonesia terdapat banyak lembaga permasyarakatan yang jumlah narapidana dan tahanan melebihi dari kapasitas lapas atau rutan tersebut. Sebagai contoh terdapat 16.830 orang narapidana pada lapas atau rutan di kanwil DKI Jakarta, sedangkan kapasitas lapas atau rutan hanya mampu menampung 5.791 orang tahanan dan narapidana. Sementara pada kanwil jawa barat jumlah narapidana dan tahanan sebanyak 22.848 orang, sedangkan kapasitas lapas atau rutan sebanyak 15.816 orang. ${ }^{2}$

Masalah problematika yang muncul akibat dari kepadatan di dalam lembaga pemasyarakatan adalah di antara nya adalah pembinaan atau pembenahan yang terjadi di dalam lembaga pemasyarakatan tidak berjalan sesuai apa yang di targetkan atau yang akan di raih, sulitnya pengawasan narapidana serta pengamanan di lembaga pemasyarakatan, semakin memburuknya psikologis narapidana dan juga psikologis petugas pemasyarakatan, rentannya konflik antar

\footnotetext{
${ }^{1}$ Surat Keputusan Menteri Kehakiman Republik Indonesia no. 02-PK.04.10 tahun 1990

${ }^{2}$ http://smslap.ditjenpas.go.id/public/grl/current/monthly/year/2018/month/4
} 
penghuni lembaga pemasyarakatan, rentanya terjadi penyelewengan seksual antar narapidana, rusaknya sitem sanitasi di lembaga pemasyarakatan, semakin memburuknya kesehatan narapidana, dan terjadi pembrosan anggaran negara akibat meningkatnya konsumsi pangan dan sandang seluruh narapidana. ${ }^{3}$ Berdasarkan realitas di lapangan mengenai kondisi yang dihadapi oleh lembaga pemasyarakatan akibat dari kondisi lapas yang melebihi kapasitas daya tampung narapidana. Akan berdampak pada dependensi atau bahkan kesukaran berbagai fasilitas universal maupun privat yang seyogyanya diperuntukkan narapidana.

Realitas diatas didukung dengan pernyataan Menteri Hukum dan HAM RI Yasonna Laoly yang mengungkapkan bahwa prosentase narapidana membludak hingga terjadi peningkatan kelebihan daya tampung penghuni lembaga pemasyarakatan tahun 2018 mencapai 203\%, terjadi peningkatan jumlah penghuni lapas sejumlah 24.197 orang. Pada tahun 2018 juga jumlah penghuni lapas sejumlah 256.273 orang padahal jumlah daya tampung lembaga pemasyarakatan hanya 126.614 orang.

Sebagai upaya mengatasi pemasalahan yang muncul akibat over kapasitas pemerintah telah menggambil beberapa kebijakan diantaranya dengan melakukan pembaharuan bangunan maupun membuat bangunan baru. Salah satu upaya lain yang dapat dilakukan guna mengatasi hal tersebut dengan melakukan pendekatan Restorative Justice, yaitu pendekatan dengan menekankan pada pelaku tindak pidana dan melibatkan secara langsung korban tindak pidana saat proses menentukan keperluan hasil akhir dari kasus tindak pidana yang dialaminya.

Dalam pelaksanaannya seorang pelaku tindak pidana akan di berikan suatu rehabilitasi dan menyatukan mereka kembali ke tengah tengah masyarakat. Dalam melakukan hal ini di perlukan pertukaran informasi antara pelaku tindak pidana dengan korban secara langsung, sehingga nantinya pelaku dan korban dapat enentukan hal terbaik dan mendapat surplus dari suatu tindak pidana yang terjadi .

Sebagiamana yang diatur pada UU No. 12 Tahun 1995 mengenai Pemasyarakatan, Program kebijakan yang ada mengenai rehabilitasi dan reintegrasi sosial itu meliputi asimilasi yang dikemas dalam berbagai macam program pembinaan yang salah satunya adalah pemberian latihan kerja dan produksi kepada narapidana. Adanya model pembinaan bagi narapidana di dalam Lembaga Pemasyarakatan tidak terlepas dari sebuah dinamika, yang bertujuan untuk lebih banyak memberikan bekal bagi Narapidana dalam menghadapi kehidupannya saat bebas dari hukuman.

Kegiatan dalam Lembaga permasyarakatan tidak hanya menghukum atau menjaga narapidana tetapi mencakup proses pembinaan agar warga binaan menyadari kesalahan dan memperbaiki diri serta tidak mengulangi tindak pidana yang pernah dilakukan. Dengan begitu apabila mereka nantinya bebas, mereka dapat diterima kembali oleh masyarakat dan lingkungannya dan dapat hidup secara wajar seperti sedia kala. Fungsi pemidanaan tidak lagi sekedar penjeraan tetapi juga merupakan suatu proses rehabilitasi dan reintegrasi sosial warga binaan yang ada di dalam Lembaga permasyarakatan. Hal tersebut sangat bertentangan apabila dibandingkan dengan langkah pemasyaratan mencapai tujuannya sebagai tempat pembinaan, agar sewaktu bebas mereka dapat diterima kehadirannya. ${ }^{4}$

Berdasarkan pada fenomena yang terjadi dapat disimpulkan bahwa lembaga permasyarakatan selaku pelaksana dan pemberi pembinaan bagi narapidana bertujuan untuk melakukan reintegrasi sebagai upaya memberikan modal sosial serta membangun kembali kepercayaan diri pada narapidana untuk menjadikannya manusia yang lebih baik sebelum ia kembali ditengah-tengah lingkungan masyarakat. Permasalahan penelitian berhubungan dengan hal tersebut, yaitu mengenai faktor yang berhubungan dengan overcapacity meliputi pemicu dan solusi dalam upaya optimalisasi pembinaan kepada para narapidana menjadi krusial untuk di bahas dan di bicarakan sebagaimana yang tersaji pada tulisan ini.

\section{Identifikasi Masalah}

Berdasarkan latar belakang yang telah dijelaskan diatas, penulis mengidentifikasi masalah-masalah yang ada dalam penelitian sebagai berikut :

1. Apa faktor penyebab over kapasitas di lembaga permasyarakatan

2. Bagaimana dampak over kapasitas terhadap pembinaan yang dilakukan di lembaga permasyarakatan

3. Solusi mengatasi over kapasitas terhadap optimalisasi pembinaan di lembaga permasyarakatan

\section{HASIL DAN PEMBAHASAN}

Sesuai dengan UU No. 12 Tahun 1995, yang mendeskripsikan bahwa lapas berfungsi penyelenggara hukuman sekaligus sebagai tempat pembinaan bagi narapidana. Pada implementasinya terdapat beberapa lembaga permasayarakatan yang jumlah narapidananya melebihi kapasitas daya tampung lapas tersebut. Dengan kata lain,

${ }^{3}$ Kementerian Pemberdayagunaan Aparatur Negara dan Reformasi Birokrasi, Tenaga Administrasi akan Dialihkan Menjadi Sopir, (Jakarta: Kemenpan), diakses pada tanggal 21 Mei 2015. http://www.menpan.go.id.

${ }^{4}$ https://www.bphn.go.id/data/documents/pkj_2012_-_7.pdf 
jumlah narapidana yang ada melebihi dari jumlah kapasitas lapas, hal ini akan memberikan efek negatif terhadap kondisi narapidana sehingga pembinaan yang diberikan tidak bisa diterima secara maksimal oleh narapidana.

Berdasarkan data seluruh permasyarakatan di Indonesia ditunjukkan bahwa total jumlah narapidana dan tahanan yang tersebar di lembaga permasyarakatan atau rutan per desember 2018 sebanyak 255.380 orang, sedangkan daya tampung keseluruhan hanya sebanyak 132.107 orang. Hal ini menunjukkan bahwa persentase over kapasitas sebesar 93\%. Disimpulkan bahwa jumlah narapidanya melebihi daya tampung laembaga permasyarakatan sehingga berdampak pada over kapasitas lapas. Sebagai upaya menyikapi permasalahan yang muncul pada lembaga permasyarakatan mengenai jumlah narapidana dan tahanan yang melebihi kapasitas, pemerintah telah mengambil beberapa kebijakan diantaranya melalui perbaikan bangunan atau rehabilitasi hingga pembuatan gedung baru agar dapat menambah daya tampung pada lapas. Tetapi, kebijakan tersebut belum sepenuhnya dapat mengatasi permasalahan yang muncul mengingat masih tingginya tingkat tindakan kriminalitas yang terjadi di masyarakat sehingga akan berdampak pada jumlah tahanan atau narapidana yang akan terus beranjak.

Penyelesaian problema over kapasitas harusnya berpusat pada mekanisme sebelum masuknya pelaku kriminal tersebut ke dalam lapas yakni pada tahap penyidikan di kepolisian, penuntutan di kejaksaan, sampai ke tahap putusan pengadilan. Hal ini sangat penting agar tidak semua pelaku kejahatan harus masuk ke lembaga pemasyarakatan padahal beberapa tindak pidana justru dapat diselesaikan di tingkat kepolisian dan kejaksaan tanpa harus dilakukan hukuman badan berupa pemidanaan.

Kondisi narapidana dalam lembaga permasyarakatan merupakan problem serius dalam menjadikan narapidana yang terpuji. Seperti yang disampaikan Woolf, dalam mengelola lapas perlu memerhatikan faktor yang dapat memperburuk kondisi dalam lapas, diantaranya ; Kepadatan penjara yang extreme; Kelebihan penghuni; keadaan penjara yang buruk (baik bagi napi serta staff lapas); minimnya jumlah staff; Staf penjara yang saling rusuh; Buruknya sistem keamanan; "Campuran Beracun" dari panjangnya jangka waktu serta penahanan selama seumur serta mental dari tahanan yang terganggu; Kerusuhan diantara para tahanan.

Banyaknya napi yang masuk dengan jumlah narapidana yang bebas tidak seimbang, jumlah narapidana baru tak sebanding dengan jumlah masa pidana penjaranya dan jumlah narapidana yang bebas ${ }^{5}$. Selain itu lembaga permasyarakatan selain tempat hunian bagi narapidana tetapi juga bagi petugas lapas tentunya kapasitas di dalamnya harus sesuai dengan jumlah penghuni yang ada. Dengan adanya kapasitas hunian yang proporsional maka dapat mendukung pelaksanaan pelayanan dari petugas lapas maupun untuk narapidana.

Kondisi lapas yang melebihi daya tampung akan berdampak pada SDM petugas maupun psikologi narapidana. Problema overcapacity akan berimbas terhadap kurang optimalnya pengawasan serta perawatan yang dilakukan oleh petugas lembaga pemasyarakatan dan mengakibatkan tidak tercapainya tujuan dari sistem pemidanaan. Hal ini tentu saja akan dampak pada bertambahnya penyelewengan yang terjadi dalam lapas 6 .

Pemidanaan dimaksudkan untuk membenahi dan membentuk seorang narapidana menjadi orang yang berakhlak sehingga bermanfaat bagi masyarakat serta memulihkan tatanan keseimbangan, keharmonisan dan keserasian dalam masyarakat ${ }^{7}$. Pemberian sanksi pada pelaku tindak pidana bukan hanya sebagai pemberian efek jera tetapi bertujuan untuk menyadarkan ia atas kesalahan yang telah dilakukan, sehigga menjadikannya pribadi yang berakhlak dan berintegritas sehingga mampu menyatu dengan lingkungan masyarakat saat ia bebas dari pidana.Pembinaan yang dilakukan harusnya tidak semata-mata dilakukan oleh petugas laembaga permasyarakatan dan pemerintah tetapi juga harus didukung oleh masyarakat sekitar. Keperdulian yang diberikan oleh masyarakat akan memberikan dampak positif terhadap diri narapidana, hal ini akan mampu menjadikan motivasi sehingga akan menumbuhkan kepercayaan diri narapidana untuk menjadi pribadi yang lebih baik.

Namun pada kenyataannya minimnya kepedulian masyarakat terhadap kesejahteraan napi karena sebagian anggota masyarakat masih enggan dan tidak mau menerima kembali bekas napi. Sehingga hal tersebut lah yang menyebabkan belum tercapainya tujuan dari konsep pemidanaan, yaitu untuk memasyarakatkan kembali narapidana ke dalam lingkungan masyarakat. Kondisi tersebutlah seperti yang terjadi pada Lembaga Pemasyarakatan di kota Magelang, kurangnya partisipasi dari masyarakat Magelang dalam membantu proses pembinaan narapidana, hal ini disebabkan oleh kurangnya kepedulian serta hubungan baik dari lembaga pemasyarakatan dengan masyarakat ${ }^{8}$. Dalam pencapain keberhasilan dalam pembinaan narapidana dibutuhkan dukungan kerja sama antara lapas dan masyarakat.

5 Angkasa. "Over Capacity Narapidana di Lembaga Pemasyarakatan, Faktor Penyebab, Implikasi Negatif, Serta Solusi dalam Upaya Optimalisasi Pembinaan Narapidana”, Jurnal Dinamika Hukum, Vol. 10 No. 3, (2010), hlm. 214.

6 Desy Maryani, "Faktor-Faktor Penyebab Tidak Tercapainya Tujuan Pemidanaan Lembaga Pemasyarakatan di Indonesia", Jurnal Hukum Sehasen, Vol. 1 No. 1, (2015), hlm. 14.

${ }^{7}$ Andi Hamzah, Sistem Pidana dan Pemidanaan dari Retribusi ke Reformasi, Prad Pramita, (1986), hlm. 28.

8 Budi Hermidi, Pembinaan Narapidana Sebagai Upaya Untuk Mewujudkan Tujuan Pemidanaan (Studi Kasus di Lembaga Pemasyarakatan Magelang), Semarang: Universitas Diponegoro, (2001), hlm. 20. 


\section{Faktor penyebab overcapacity di lembaga pemasyarakatan}

Overcapacity adalah situasi pada suatu tempat dimana jumlah penghuni pada tempat tersebut melebihi dari daya tampung. Pada lembaga permasyarakat over capasity terjadi akibat peningkatan jumlah narapidana yang masuk pada lembaga permasyarakatan tidak seimbang dengan jumlah daya tampung pada tempat tersebut. Pertumbuhan jumlah narapidana yang masuk merupakan dampak dari semakin tingginya tindak kriminalis yang terjadi di masyarakat.

Selain banyaknya kenaikan kaus tindak pidana yang terjadi, terkandung aspek pendorong lain dalam terjadinya over capacity paradigma atau aspek hukuman tersebut. Tafsir hukum ini ialah hukum yang utamanya hukum pidana materiil, formil dan hukum pelaksanaan pidana penjara. Beberapa pengamat menyatakan bahwa politik pemidanaan saat ini yang tidak tepat sehingga setiap orang dapat dengan mudah masuk penjara dan menyebabkan kondisi lembaga pemasyarakatan menjadi overcapacity. Disini perlu pemerintah untuk merevisi KUHP dan KUHAP yang dimilki saat ini di rasa sudah tidak sangat relevan dengan kondisi sekarang 9 .

Dalam Undang-undang dijelaskan bahwa proses penyelidikan, penyidikan, penuntutan, pemeriksaan di pengadilan, dan pelaksanaan pidana terangkum dalam sebuah sistem peradilan pidana terpadu (integrated criminal justice system). ${ }^{10}$ Dalam susunan tatanan tersebut salah satu lembaga yang bertanggungjawab dalam penegakan hukum yaitu Lembaga Pemasyarakatan.Berdasarkan sistem permasyarakatan, lembaga pemasyarakatan berfungsi untuk melakukakan pelaksanaan putusan yang telah dijatukan kepada terpidana. Pelaksaaan pidana dilakukan bukan hanya bertujuan sebagai pemberian sanksi terhadap pelaku pidana.

Sesuai ketentuan UU No. 12 Tahun 1995 Pasal 1angka (2), tatanan pemasyarakatan merupakan suatu bentuki arah dan batas serta cara pembinaan warga binaan pemasyarakatan berdasarkan Pancasila yang dilaksanakan secara terpadu antara pembina, yang dibina, dan masyarakat untuk meningkatkan kualitas warga binaan Pemasyarakatan agar menyadari kesalahan memperbaiki diri, dan tidak mengulangi tindak pidana sehingga dapat diterima kembali oleh lingkungan masyarakat, dapat aktif berperan dalam pembangunan, dan dapat hidup secara wajar sebagai warga yang baik dan bertanggungjawab.

Berkaitan dengan pasal tersebut, dalam implementasinya banyak yang beranggapan bahwa narapidana merupakan orang yang telah melakukan tindak kriminalitas sehingga memilki nilai negatif pada masyarakat. Mantan narapidana cenderung dikucilkan dalam lingkungan karena dianggap tidak memilki potensi yang baik, memilki kelakuan yang buruk. Ini menunjukkan bahwasannnya terjadi perubahan kondisi dalam kehidupan masyarakat. Perlunya adanya solusi atas pemberian sanksi selain pidana bagi orang yang telah melakukan tindakan kriminalitas. Banyaknya pertumbuhan jumlah narapidana dari tahun ketahun yang berdampak pada over kapasitas juga menjadi permasalahan penting yang harus segera ditanggani. Perlu adanya opsi baru pada sistem pelaksanaan pidana yang mendahulukan pada hak asasi manusia.

Dalam konteksnya pelaksanaan pidana penjara Pasal 12 UU No. 12 tahun 1995 mengenai Pemasyarakatan, maka narapidana ditempatkan dan dibina berdasarkan karakteristiknya, sehingga tujuan pembinaan dapat tercapai. Dalam pelaksanaannya tidak sesuai dengan isi Pasal 12 sebagaimana yang tercantum dalam UU Nomor 12 Tahun 1995 tersebut,karena jumlah narapidana melebihi kapasitas sehingga penempatan narapidana berdasarkan umur, jenis kejahatan, dan lamanya pidana tidak dapat terwujud.

Kelebihan daya tampung pada Lapas di Indonesia terjadi pada hampir seluruh kanwil lembaga pemasyarakatan. Dari 33 kanwil pelaksana, hanya terdapat 4 kanwil yang tidak mengalami over kapasitas, sementara sisanya mengalami kelebihan daya tampung (http://smslap.ditjenpas.go.id). Berdasarkan fenomena tersebut, ditunjukkan banyaknya dampak dari pidana penjara yang diterapkan dalam KUHP di Indonesia. Sanksi atau hukuman condong terhadap hukuman pidana. Kelebihan daya tampung akan berimpas pada sulitnya perwujutan dari gagasan pemasyarakatan mengenai rehabilitasi.

Pada pelaksanaannya pidana yang diberikan akan menjadi kurang efektif akibat jumlah narapidana dalam lapas yang tidak berimbang dengan jumlah bangunan Lembaga Pemasyarakatannya. Pelaksanaan pidana penjara yang merupakan rangkaian dari tatanan peradilan pidana perlu segera dilakukan reorientasi mengingat sebagian besar sanksi pidana yang sekarang baik itu dalam Kitab Undang-Undang Hukum Pidana (KUHP) maupun dalam konsep Kitab Undang-Undang Hukum Acara Pidana Baru masih menggunakan bentuk sanksi berupa kurungan penjara. Pada implementasinya belum adanya kesesuaian antara aturan pelaksanaan dengan tujuan pemasyarakatan.

Terlihat jelas bahwa over kapasitas terjadi pada hampir seluruh unit pelaksana lapas di indonesia. Masalah yang timbul akibat dari over kapasitas masih belum kunjung menunjukkan titik terang. Faktor lain dari munculnya over kapasitas pada lapas ialah penerapan pidana alternatif belum optimal, kasus pidana pencurian ringan seperti pencurian buah, sayur, ayam seharusnya dberikan pidana bersyarat, bukan pidana kurungan penjara. Peraturan

${ }^{9}$ http://www.rakyatmerdeka.co.id

${ }^{10}$ Hutabarat, R. R. (2017). Problematika Lembaga Pemasyarakatan dalam Sistem Peradilan Terpadu. Jurnal Muara Ilmu Sosial, Humaniora, dan Seni, 1(1), 42-50. 
pemberian cuti bersyarat maupun pembebasan bersyarat dapat digunakan sebagai upaya mengurangi kelebihan kapasitas di lapas/rutan.

Solusi tersebut sesuai dengan bunyi Implementation of The Standar Minimum Rules for the Treatment of Prisoners point 11 yang menyatakan bahwa "Kebijakan untuk menegakkan aturan di dalam lembaga pemasyarakatan tidak akan efektif manakala pada saat yang bersamaan tidak diambil langkah-langkah untuk mengatasi gejala over kapasitas. Usaha-usaha pembinaan terhadap narapidana harus didahului dengan program yang bertujuan untuk menyusutkan isi Lapas/Rutan sesuai dengan fasilitas dan sarana yang tersedia".

Dapat ditarik kesimpulan bahwa problema over kapasitas penjara dapat berpengaruh pada efektivitas penyelenggaraan pembinaan lapas. Perlu adanya upaya untuk meminimalisir atas dampak yang ditimbulkan akibat over kapasitas.

Lembaga permasyarakatan sebagai tempat pelaksana pembinaan para narapidana diharapkan mampu untuk dapat mewujudkan tujuan dari sistem pidana, yakni melakukan rehabilitasi dan memberikan pendidikan melalui resosialisasi atau proses pembelajaran norma, nilai, sikap dan perilaku.

\section{Over kapasitas membuat pembinaan menjadi negatif}

Berkaitan dengan over capasitas pada lembaga permayarakatan. Over kapasitas cenderung memiliki hubungan keterlibatan yang negatif yang akan menimbulkan rendahnya tingkat pengamanan/ pengawasan. Pola pengamanan yang rendah akan menimbulkan berbagai permasalahan baru, misalnya kaburnya narapidana dari lapas, terjadinya kerusuhan antar narapida. Sehingga program pembinaan yang dilaksanakan tidak dapat bejalan secara optimal dan sesuai dengan prinsip dari permasyarakatan.

Secara teori over capacity dapat menyebabkan dan menimbulkan prisonisasi ${ }^{11}$. Permana (2011) dalam penelitiannya menyataka bahwa prisonisasi ialah mekanisme penyerapan rancangan kehidupan dalam lapas. Mekanisme ini dilakukan melalui proses belajar dalam berinteraksi dengan sesama narapidana. Proses pembelajaran tersebut berkaitan erat dengan pola tatanan kehidupan narapidana ketika berada dalam lembaga permasyarakatan. Pengaruh kebiasaan serta moral narapidana selama berada tatanan kehidupan dalam lembaga permasyarakatan, sedikit banyak akan berpengaruh terhadap sikap dan perilaku narpidana.

Pada penelitian Tjahjani, J. (2019), Sykes dengan "pains of impri- sonment theory" mengatakan bahwa pada hakikatnya prisonisasi terbentuk sebagai respon terhadap masalah-masalah penyesuaian yang dimunculkan sebagai akibat pidana penjara itu sendiri dengan segala bentuk perampasan ${ }^{12}$. Pada hakekatnya prisonisasi terbentuk sebagai umpan balik terhadap semua problema penyesuain yang muncul sebagai akibat pidana penjara itu sendiri dengan segala bentuk perampasan. Disini penyesuaian sebagai pereda rasa sakit terhadap penderitaan sebagai akibat perampasan ${ }^{13}$. Maksud dari perampasan dalam hal ini yaitu hilangnya kebebasanan dari narapidana, sehingga mereka harus berdesak-desakan akibat dari daya tampung di lapas yang tidak seimbang dengan banyaknya jumlah narapidana.

Over kapasitas yang berdampak pada kehidupan narapidana selain berakibat pada perampasan kebebasan narapidana. Hal tersebut juga cenderung menghadapkan narapida pada dua pilihan diantaranya, narapidana harus tetap mengikuti aturan atau ketentuan yang telah ditetapkan oleh petugas lapas yakni tidak adanya kebebasan bagi mereka. Pilihan lain adalah narapidana harus mengikuti budaya atau kebiasaan oranga-orang dalam lapas.

Beberapa bentuk prisonisasi diantaranya terjadinya hal berupa perampasan sesama narapidana, pencurian dari dalam sel, perkelahian yang terjadi kelompok narapidana maupun secara perorangan, munculnya kelompok-kelompok yang dibuat antar narapidana, serta rasa untuk melindungi sesama narapidana. Prisonisasi tampaknya belum sejalan dengan program pembinaan sebagi tujuan utama dari pemasyarakatan. Sisi negatif dari lapas berasal dari suatu kenyataan dimana struktur sosial yang terjadi antar narapidana terkadang sangat menunjang mereka untuk melindungi sesama narapidana yang menurut mereka sangat menyiasati struktur tingkah laku kriminal dan sebaliknya terdapat bebrapa kalangan narapidana yang tidak memberikan dukungan bahkan melakukan penindasan atau pengancaman terhadap narapidana yang dianggap masih menunjukan loyalitas pada dunia non kriminalitas.

Pada hakikatnya prisonisasi memiliki dampak negatif terutama bagi narapidana baru. Dalam penjara terdapat berbagai macam orang dengan latar belakang yang berbeda seperti pelaku tindak kriminalitas yang masih baru maupun pelaku yang memilki riwayat kejahatan yang kronis. Banyak hal yang dapat terjadi di dalam penjara, adanya pelaku tindak kriminalitas yang memilki riwayat kejahatan yang buruk dapat memberikan efek terhadap narapidana

${ }^{11}$ Prisonisasi atau Prisonization adalah istilah yang dicipta- kan oleh Donald Clemmer yang dikonsepkan sebagai "The taking on, in greater or lesser degree, of the falk-ways, more, customs and general culture of the peni- tentiary" (Stanton Wheeler, "Socialication in Correc-tiomal Institutions" dalam Sir Leon Radzinowichz and Marvis E Wolfgang (ed), Crime and Justice. New York: Basic Books, Inc. Publishers, tanpa tahun hlm.194)

${ }^{12}$ Loc.cit., hlm. 197.

13 Roger Hood and Richard Sparks, 1978. Key Issues in Criminology. Wiedenfeld and Nicolson, London: World University, hlm. 222. 
lain, sehingga pengalaman yang ia peroleh dapat menjadikannya mengikuti alur kejahatan yang dilakukan oleh narapidana lain dengan kata lain akan adanya penularan perilaku atau sikap antar narapidana. Hal tersebut sesuai dengan teori edwin sutherland pada Daffanur, F. (2018) yang menyatakan bahwa kejahatan berasal dari sesuatu yang dipelajari.

Pergaulan yang terjadi antar narapidana dengan narapidana lain secara terus-menerus perlu adanya pemberian kegiatan positif seperti dengan pemberian pembinaan kemandirian dan kepribadian. Pembinaan tersebut dapat dilakukan dengan kegiatan kerohanian serta mengikut sertakannarapida pada program keterampilan. Dengan demikian akan memberikan sebuah dasar maupun pengalaman yang dapat mereka terapkan ketika mereka bebas dan kembali pada lingkungan masyarakat. Jika masalah over kapasitas tidak segera diatasi maka kecenderungan narapidana untuk mengikuti hal negatif yang telah dilakukan oleh narapidana lain, bukan tidak mungkin akan berakibat pada tindak kriminalitas yang semakin banyak sehingga over kapasitas pada lembaga permasyarakaan akan terus mengalami peningkatan.

Berkaitan dengan hal ini kongres PBB ke-5 pada tahun 1975 dalam salah satu laporannya mengungkapkan bahwasannya pengalaman selama di penjara amat membahayakan sehingga dapat menjadi penghalang dan perusak serius pada pelanggar hukum untuk mampu mulai kembali pada keadaan patuh dengan hukum setelah nantinya selesai menjalani masa pidana di lembaga pemasyarakatan.

\section{Overcapacity dan solusi bagi narapidana di dalam lembaga pemasyarakatan agar pembinaan berjalan optimal}

Banyak kebijakan dalam rangka untuk menekan angka overcapacity nampaknya banyak di lakukan diantaranya dengan banyaknya pembangunan kamar baru bagi narapidana, pembaharuan bangunan lapas hingga dengan pembangunan lapas baru dengan tujuan utama menambah kapasitas narapidana, akan tetapi hal ini nampaknya tidak terlalu signifikan dalam menyikapi permasalahan overcapacity mengingat jumlah narapidana yang masuk tak sebanding dengan jumlah narapidana yang keluar dari lembaga pemasyarakatan, di tambah lagi pembangunan lapas baru membutuhkan waktu yang lumayan cukup lama dan juga biaya yang sangat besar.

Pada peraturan menteri depkumham pada tahun 2007 yang tertuang dalam permen depkumham no.M.2.PK.04-10 tahun 2007 di lakukan penyederhanaan dalam pemberain hak narapidana antara lain pemberian penyederhanaan persyaratan pembesan bersyarat, cuti bersyarat, dan cuti menjelang bebas. Melalui kebijakan ini memang dapat mengurangi kepadatan hunian narapidana di lembaga pemasyarakatan. Sebagai contoh pada tahun 2007 sebanyak 5000 narapidana di jawa barat dapat di bebaskan. Akan tetapi hal ini membuat pertanyaan tentang kualitas keluaran dari lembaga pemasyarakatan masyarakat juga melihat eks perilaku kejahatan yang mendapat hal tersebut dapat melukai rasa keadilan.

Berkaitan dengan hal tersebut, dibutuhkan temukan cara lain dalam rangka menguragi tingginya angka over capasity. Beberapa tindakan yang bersifat non institusional antara lain pemberian pidana bersyarat, probation, pidana yang di tangguhkan, kompensasi, restitusi, dan sebagainya. Dalam masa kini perkembangan restorative justice tampaknya dapat mengurangi populasi dari narapidanadalam lembaga pemasyarakatan dan tentu aspek keadilan akan tetap dapat tercapai dnegan baik. Beberapa tindalan non institusional tersebut dapat di jelaskan antara lain,Pidana bersyarat, Secara normatif di atur dalam ketentuan pasal 14a KUHP sampai pasal 14f KUHP dengan segala peraturan pelaksanaanya. Hal ini menjadikan yang bersangkutan tidak harus menjalankan masa pidana di dalam lembaga pemasyarakatan dengan ketentuan mereka memenuhi beberapa hal tertentu, tentu hal ini akan dapat sangat mengurangi populaasi narapidana di lembaga pemasyarakatan. Hal ini juga menjadi pidana alternatif dalam perampasan kemerdekaan dan hampir sama dengan probation, keuntungan pertama narapidana dapat memperbaiki dirinya di tengah tengah masyarakat secara langsung, kedua dapat memungkinkan narapidana melanjutkan kebiasaankebiasaan sebagai manusia, ketiga mencegah terjadinya stigma dari masyarakat yang akibat dari perampasan kemerdekaan. Kedua adalah restitusi yang secara umum merupakan tindakan restutif berkaitan dengan pelaku tindak pidana yang berkarakter pemidanaan dan menggambarkan suatu tujuan koreksional dalam kasus pidana, keuntungan antara lain mengurangi jumlah narapidana di lapas, mengurangi beban pembiayaan pemerintah.

Restitusi berkaitan dengan perbaikan dari kerugian fisik, moral mau pun harta benda, kedudukan dan hak-hak kor- ban atas serangan pelaku tindak pidana (pen- jahat). Restitusi merupakan suatu tindakan restitutif terhadap pelaku tindak pidana yang berkarakter pidana dan menggambarkan suatu tujuan koreksional dalam kasuspidana ${ }^{14}$.

Restitusi dalam kaitannya dengan over- capacity, bermanfaat bila diintegrasikan dengan lembaga pidana bersyarat, implikasinya mengurangi populasi hunian pen- jara (Lapas) sekaligus penghematan dana pe- ngeluaran pemerintah. Dengan tidak masuknya pelaku menjalani pidana penjara di Lapas maka pemerintah dapat menghemat dana yang seharusnya dikeluarkan untuk memberi makan, perawatan serta pembinaan bagi napi ${ }^{15}$.

\footnotetext{
${ }^{14}$ Angkasa, 2004. Kedudukan Korban dalam Sistem Peradilan Pidana (Pendekatan Viktimologisterhadap

Korban Tindak Pidana Perkosaan (Disertasi), Semarang: Universitas Diponegoro, hlm.129.

${ }^{15}$ Angkasa, 2004, Op.cit., hlm.57; Bandingkan dengan hasil
} 
Upaya lain yang dapat dilakukan untuk mengatasi masalah over kapasitas pada lembaga permasyarakatan adalah dengan melakukan pendekatan secara restorative justice. Pendekatan restorative justice adalah pendekatan dengan menekankan pada pelaku tindak pidana dan melibatkan korban secara langsung dalam proses penentuan keperluan hasil akhir kasus yang dialaminya.

Russ Immarigeon mengungkapkan bahwa Restoratif justice atau keadilan restoratif ialah proses dimana semua pihak yang terlibat dalam suatu pelanggaran tertetentu, bersatu dalam menyelesaikannya secara kolektif mengenai bagaimana menanggani setelah pelanggaran dan hasil akhir untuk masa depan. ${ }^{16}$.

Sependapat dengan Edwira, M. R. (2018) yang menyatakan bahwa upaya perdamaian di luar pengadilan dengan maksud dan tujuan agar permasalahan hukum yang timbul akibat terjadinya perbuatan pidana tersebut dapat diselesaikan dengan tercapainya persetujuan dan kesepakatan kedua belah pihak. Hal tersebut sesuai dengan peryataan Meliala, A. (2005) yang menyatakan bahwa menyelesaikan permasalahan hukum pidana yang terjadi diantara pelaku tindak pidana dan korban tindak pidana tersebut apabila tercapai persetujuan dan kesepakatan diantara para pihak.

Dengan adanya berbagai sosusi diantaranya adanya kebijakan pemerintah mengenai upaya untuk mengatasi over kapasitas pada lembaga permasyarakatan, hal tersebut dapat ditempuh dengan cara lain misalnya dengan melakukan pendekatan restorative justice. Hal tersebut diharapkan mampu mengurangi jumlah narapidana sehingga kapasitas lembaga permasyarakatan dapat digunakan sebagaimana mestinya. Selain itu sisi positif dari adanya pendekatan ini yakni program pembinaan yang diberikan kepada narapidana akan dapat berjalan secara optimal sehingga tujuan dari sistem permasyarakatan dapat dijalankan secara maksimal.

\section{SIMPULAN}

Terjadinya peningkatan jumlah penghuni lapas akan memicu adanya permasalahan overcapacity. Pemasyarakatan adalah lembaga yang yang berfokus pada pembinaan dari pelanggar hukum, dengan adanya over capacity dalam lembaga pemasyarakatan membuat pembinaan tidak bisa berjalan dengan sebagaimana mestinya sehingga dapat menyebabkan terjadinya penyimpangan. Prisonisasi tampaknya belum sejalan dengan program pembinaan sebagi tujuan utama dari pemasyarakatan. Dalam upaya pengurangan jumlah populasi di lembaga pemasyarakatn di perlukan peran pemerintah seperti pemberian pidana non institusional seperti pemberian pidana bersyarat, restitusi, dan perlakuan program restorative justice, tentu hal ini harus dengan komitmen dan pengawasan dari seluruh komponen dari lembaga pemasyarakatan.

\section{Saran}

Berdasarkan hal tersebut di atas untuk dapat mengatasi overcapacity narapidana di dalam lembaga pemasyarakat ataupun rumah tahanan yang cenderung berimplikasi negative pada tujuan pemidanaan antara lain berupa terjadinya prisonosasi dan rawannya sistem pengamanan maka, penyelesaian perkara pidana perlu menggunakan pendekatan baru yakni restorative justice.

\section{DAFTAR PUSTAKA}

Andi Hamzah, Sistem Pidana dan Pemidanaan dari Retribusi ke Reformasi, Prad Pramita, (1986), hlm. 28.

Angkasa. 1993. Prisonisasi dan Permasalahan- nya Terhadap Pembinaan Narapidana (Suatu Studi di Lembaga Pemasyarakatan Semarang dan Lembaga Pemasyarakatan Purwokerto. Semarang: Program Pasca- sarjana Bidang Ilmu Hukum Undip;

2004. Kedudukan Korban dalam Sistem Peradilan Pidana (Pendekatan Viktimolo- gis terhadap Korban Tindak Pidana Per- kosaan (Disertasi). Semarang: Universitas Diponegoro;

Atmasasmita, Romli. 1983. Kepenjaraan dalam suatu bunga rampai. Bandung; Armico

Budi Hermidi, Pembinaan Narapidana Sebagai Upaya Untuk Mewujudkan Tujuan Pemidanaan (Studi Kasus di Lembaga Pemasyarakatan Magelang), Semarang: Universitas Diponegoro, (2001), hlm. 20.

DAFFANUR, F. (2018). PENJARA YANG TIDAK MENJERAKAN (Studi Tentang Kehidupan Narapidana Residivis pada Lembaga Pemasyarakatan di Jakarta) (Doctoral dissertation, Universitas Airlangga)

Desy Maryani, "Faktor-Faktor Penyebab Tidak Tercapainya Tujuan Pemidanaan Lembaga Pemasyarakatan di Indonesia", Jurnal Hukum Sehasen, Vol. 1 No. 1, (2015), hlm. 14.

studi Lawrence (1990) yang menunjukkan bahwa dari sejumlah 3000 pelaku tindak pidana di Texas selama 7 tahun terakhir, lebih memilih program restitusi daripada program pidana penjara biasa. Program restitusi ini hanya mengeluarkan biaya \$215, sedangkan program pemenjaraan biayanya sebesar \$ 750. Studi lain dari Hudson \& Galaway (1980); Lawrence (1990); Patterson (1978), juga melaporkan bahwa restitusi lebih ekonomis daripada dengan prosedur sistem peradilan pidana biasa. (William G. Doerner, Steven P. Lab,Loc.cit.)

${ }_{16}$ Tony Marshall, 1999, Restorative Justice: An Overview.London: Home Office Research Development and Statis- tics Directorate, hlm. 5. 
Risang Achmad Putra Perkasa, Optimalisasi Pembinaan Narapidana dalam Upaya Mengurangi Overcapacity Lembaga Pemasyarakatan

Edwira, M. R. (2018). PENDEKATAN RESTORATIVE JUSTICE SEBAGAI UPAYA MENGURANGI OVER KAPASITAS LEMBAGA PEMASYARAKATAN.

https://www.bphn.go.id/data/documents/pkj_2012__ 7.pdf

http://www.rakyatmerdeka.co.id

Hutabarat, R. R. (2017). Problematika Lembaga Pemasyarakatan dalam Sistem Peradilan Terpadu. Jurnal Muara Ilmu Sosial, Humaniora, dan Seni, 1(1), 42-50.

Kementerian Pemberdayagunaan Aparatur Negara dan Reformasi Birokrasi, Tenaga Administrasi akan Dialihkan Menjadi Sopir, (Jakarta: Kemenpan), diakses pada tanggal 21 Mei 2015. http://www.menpan.go.id.

Loc.cit., hlm. 197.

Muladi, 1985. Lembaga pidana bersyarat. Bandung; alumni

Muladi dan Barda Nawawi Arief.1984. teori teori kebijakan pidana. Bandung.

Permana, D. Prisonisasi Dan Masalahnya Dalam Sistem Pemasyarakatan (Studi Kasus Pada Lembaga Pemasyarakatan Klas I Tanjung Gusta Medan) (Master's thesis)

Prisonisasi atau Prisonization adalah istilah yang dicipta- kan oleh Donald Clemmer yang dikonsepkan sebagai "The taking on, in greater or lesser degree, of the falk-ways, more, customs and general culture of the penitentiary" (Stanton Wheeler, "Socialication in Correc- tiomal Institutions" dalam Sir Leon Radzinowichz and Marvis E Wolfgang (ed), Crime and Justice. New York: Basic Books, Inc. Publishers, tanpa tahun hlm.194)

Russ Immarigeon, 1999, "The Impact of Restorative Jus- tice Sanctions on the Lives and Well-Being of Crime Victims: A Review of the International Literature" in Restorative Juvenile Justice: Repairing the Harm of Youth Crime, edited by Gordon Bazemore and Lode Walgrave, Monsey, NY: Criminal Justice Press, hlm. 306.

Roger Hood and Richard Sparks, 1978. Key Issues in Criminology. Wiedenfeld and Nicolson, London: World University, hlm. 222.

Septa Juliana, Pelaksanaan Pembinaan Kemandirian Narapidanadi Lembaga Permasyarakatan Kelas II A Bengkalis Kabupaten Bengkalis, Universitas Islam Riau, hal 26.

ST.Harun Pudjiarto, HAM di Indonesia, Universitas Atmajaya: Yogyakarta, 1993, hal. 49-50, http://eprints.undip.ac.id/13284/

Surat Keputusan Menteri Kehakiman Republik Indonesia no. 02-PK.04.10 tahun 1990

Tjahjani, J. (2019). KEBIJAKAN PENGETATAN PENJATUHAN PIDANA PENJARA SEBAGAI UPAYA MENGATASI OVERCAPACITY DI LEMBAGA PEMASYARAKATAN. Jurnal Independent, 7(1), 151155.

Tony Marshall, 1999, Restorative Justice: An Overview.London: Home Office Research Development and Statis- tics Directorate, hlm. 5. 